\title{
PEMBANGUNAN HUKUM DAN HAK ASASI MANUSIA DI INDONESIA
}

\author{
Lindra Darnela*
}

\begin{abstract}
There are some changes towards law protection of human rights. UUD 1945 is not as accommodative as RIS constitution. To overome the problems, the government made an amendment to UUD 1945 section 28 , to give more law protection for buman right.
\end{abstract}

Kata kunci: pembangunan bukum, Hak Asasi Manusia, pembangunan bukum progresif

\section{A. Pendahuluan}

Pembangunan ${ }^{1}$ hukum nasional pada dasarnya merupakan upaya untuk membangun suatu tata hukum nasional yang berlandaskan kepada jiwa dan kepribadian bangsa. Secara konkrit, pembangunan nasional berarti pembentukan kaidah-kaidah hukum baru untuk mengatur berbagai bidang kehidupan masyarakat.

* Magister Hukum dan Dosen tetap Hukum Internasional UIN Sunan Kalijaga Yogyakarta.

' Secara umum pembangunan diartikan sebagai suatu kata yang digunakan untuk menjelaskan proses dan usaha meningkatkan kehidupan ekonomi, politik, budaya, infrastruktur masyarakat, dan sebagainya. Dengan pemahaman seperti itu, pembangunan disejajarkan dengan perubahan sosial. Di pihak lain, ada pandangan minoritas bahwa pembangunan adalah sebuah discourse, suatu paham, atau suatu pendirian bahkan suatu ideologi dan teori tertentu tentang perubahan sosial. Mansour Fakih, Runtubnya Teori Pembangunan dan Globalisasi, (Yogyakarta: Pustaka pelajar dan Insist Press, 2008), hal. 10. 


\section{Lindra Darnela}

Pembangunan hukum diarahkan untuk memenuhi kebutuhan hukum masyarakat yang sedang membangun, mengarahkan, mengantisipasi perubahan sosial, dan untuk mewujudkan cita-cita masyarakat adil dan makmur.

Sebagai salah satu komponen pembangunan nasional, pembangunan hukum mempunyai hubungan yang erat dan interdependensi dengan berbagai sektor pembangunan lainnya seperti ekonomi, politik, budaya dan pertahanan keamanan. Dengan demikian, pembangunan hukum bukanlah suatu proses yang otonom, melainkan sebuah proses yang heteronom. Artinya, pembangunan hukum tidak bisa dilepaskan dari sektor-sektor pembangunan lainnya.

Hubungan yang diharapkan antar berbagai sektor pembangunan adalah hubungan yang saling menunjang untuk kemajuan masingmasing, tetapi masih tetap berada dalam alur pencapaian tujuan bersama. Merumuskan antara pembangunan hukum dan bidang pembangunan lainnya bukan suatu yang mudah. Peranan hukum sebagai alat rekayasa sosial (social engineering) dalam proses pembangunan, bukan hanya berfungsi untuk mendorong dan memacu perkembangan pembangunan bidang-bidang lainnya, tetapi juga mengarahkan dan mengendalikan proses perubahan sosial agar tidak menyimpang dari cita-cita konstitusi.

Dalam keterkaitan antar berbagai sektor pembangunan, pembangunan hukum harus dilihat dari berbagi sudut pandang, sebab hukum bukan hanya menghendaki kesejahteraan lahir, tetapi yang utama adalah ketentraman hidup yang terkandung dari perasaan keadilan masyarakat. Masalah pembangunan hukum nasional, mencakup pilihan nilai, bentuk, dan isi, dan peranan sosial hukum dalam pembangunan bangsa. ${ }^{2}$

Persoalan selanjutnya adalah memilih jenis hukum yang dibutuhkan dan diutamakan. Pilihan-pilihan tersebut mengandung

${ }^{2}$ M. Busyro Muqoddas, dkk., Politik Pembangunan Hukum Nasional (Yogyakarta: UII Pres, 1992), hal. vii. 
konsekuensi dengan kelebihan dan kelemahannya tersendiri. Jika memilih hukum emansipatif, maka sasaran utamanya adalah perlindungan hak asasi manusia (HAM) dan pemenuhan rasa keadilan masyarakat. Kelemahannya, hukum ini kurang mampu melaksanakan peranan rekayasa sosial secara cepat dalam menunjang mobilitas pembangunan bidang-bidang lainnya. Hal tersebut terjadi karena penyelesaian konflik-konflik hukum yang timbul akibat proses pembangunan harus diselesaikan dengan prosedur yang panjang dan memakan waktu yang lama, sedangkan pembangunan menghendaki sesuatu berjalan secara cepat dengan biaya murah.

Sebaliknya, hukum refresif dapat memainkan peranan yang besar sebagai alat rekayasa sosial untuk mendorong dan menunjang mobilitas pembangunan. Namun, hukum yang seperti ini dalam penerapannya seringkali menerjang nilai-nilai keadilan dan HAM.

Dilema yang sama akan ditemui pula dalam menentukan nilai dasar hukum yang dituangkan dalam peraturan perundang-undangan. Jika nilai kepastian hukum dan kemanfaatan sosial yang ditonjolkan, maka ia akan mampu merekayasa mobilitas pembangunan, tetapi dalam pelaksanaannya ia juga sering menindas nilai-nilai keadilan dan hak-hak masyarakat. Namun sebaliknya, jika nilai kepastian hukum dan keadilan diutamakan, maka ia dapat memenuhi tuntutan rasa keadilan masyarakat, tetapi lamban dalam mendorong mobilisasi pembangunan.

Tulisan ini akan melihat bagaimana proses pembangunan hukum di Indonesia dalam melindungi hak-hak asasi masyarakat dan nilai-nilai keadilan, dan sekilas menggambarkan relevansinya dengan pembangunan ekonomi negara. Dalam pembahasannya, pertama akan membahas keterkaitan antara pembangunan hukum dan HAM, kemudian menggambarkan alur pembangunan hukum yang terjadi dalam sejarah Indonesia, perkembangan peraturan dalam hal mengaktualisasikan HAM, dan terakhir analisa hukum yang tepat untuk mengakomodasi persoalan HAM dengan berkaca dari sejarah pembangunan hukum sebelumnya. 


\section{B. Pembangunan Hukum dan HAM}

Istilah pembangunan hukum bisa dikatakan merupakan hal yang baru dibandingkan "pembangunan ekonomi" ${ }^{3}$ dan "pembangunan politik". Menjadi pertanyaan adalah, apa yang dimaksud dengan pembangunan hukum. Banyak definisi yang memperkaya istilah ini, namun lebih sederhananya dalam konteks Indonesia, pembangunan hukum bisa diartikan sebagai perubahan sistem hukum, dari sistem hukum kolonial dan sistem adat (yang dijiwai sistem hukum Islam), menyatu menjadi sitem hukum nasional yang menjamin terlindunginya hak-hak dasar masyarakat (civil rights). Pembangunan hukum juga berarti meninggalkan sistem hukum kolonial yang menjamin kepentingan penjajah, serta mengkompromikan hukum adat ke dalam satu sistem hukum nasional yang melindungi kepentingan masyarakat banyak (bukan hanya golongan elit).

Hak Asasi Manusia (HAM) adalah hak-hak yang dimiliki oleh manusia semata-mata karena ia manusia. Umat manusia memilikinya bukan karena diberikan kepadanya oleh masyarakat atau berdasarkan hukum positif, melainkan semata-mata berdasarkan martabatnya sebagai manusia. ${ }^{5}$ Secara obyektif HAM berhubungan dengan kodrat manusia sebagai makhluk ciptaan Tuhan. Oleh karena itu HAM memiliki dua landasan yaitu: pertama, landasan yang langsung yaitu kodrat manusia; kedua, landasan yang lebih dalam yaitu Tuhan sendiri yang menciptakan manusia. Dalam konteks negara yang diatur secara hukum, HAM terbagi dalam dua ketegori yaitu: pertama, hak-hak yang hanya dimiliki oleh para warga negara dari negara yang

${ }^{3}$ Istilah pembangunan ekonomi semakin mendapat tempat dalam ilmu ekonomi setelah Perang Dunia Kedua, meskipun akamya sudah kuat sejak Revolusi Industri. Lihat Affan Gaffar, "Pembangunan Hukum dan Demokrasi," dalam Muqoddas dkk., Politik Pembangunan Hukum, hal. 103.

${ }^{4}$ Istilah pembangunan politik telah memperkaya studi ilmu politik sudah lebih dari seperempat abad, dan di Indonesia sudah dikembangkan sekitar dua decade lebih. Lihat Ibid.

5. Jack Donnely, Universal Human Rights in Tbeory and Practice (Ithaca and London: Cornell University Press, 2003), hal. 7-21; Maurice Cranston, What are Human Rights? (New York: Taplinger, 1973), hal. 70. 
bersangkutan (hak-hak warga negara), dan kedua, hak-hak yang pada dasarnya dimiliki semua yang berdomilisi di negara yang bersangkutan. ${ }^{6}$

Dalam hukum internasonal, rumusan tentang HAM dituangkan dalam the Universal Declaration of Human Rights yang diumumkan oleh Majelis Umum PBB pada tanggal 10 Desember 1948. Deklarasi universal HAM (DUHAM) ini ditetapkan sebagai suatu norma yang tidak mengikat, sebagai common standard of acbievement, meskipun lambat laun menjadi hukum kebiasaan internasional. Dengan banyaknya tuntutan masyarakat dunia untuk memperhatikan persoalan HAM, DUHAM dengan dua kovenannya, banyak diratifikasi oleh negara-negara, sehingga kodifikasi ini diperlakukan sebagai salah satu sumber hukum internasional, yaitu perjanjian internasional (treaties). Deklarasi universal ini juga dipandang sebagai suatu kodifikasi prinsip-prinsip hukum umum yang juga merupakan sumber hukum internasional.

Dari pengertian di atas, pembangunan hukum mutlak harus mengusung hak-hak asasi manusia, baik dalam konteks ia sebagai makhluk Tuhan, maupun sebagai warga negara, dengan mengedepankan perlindungan terhadap hak-hak kelompok marginal, yang tidak diperuntungkan dalam kehidupan bernegara. Hal ini beralasan, mengingat definisi dari pembangunan hukum sendiri yang memiliki ruh untuk perlindungan HAM, dan mengingat persoalan HAM merupakan suatu prinsip yang harus melekat pada setiap kebijakan hukum berdasarkan sumber-sumber hukum internasional.

\section{Pereode Pembangunan Hukum di Indonesia}

Untuk menentukan pembangunan hukum nasional yang tepat untuk masa sekarang, maka perlu melihat sejarah pembangunan hukum masa lampau sebagai acuan dan cermin dalam menentukan langkah selanjutnya sesuai dengan cita-cita bangsa. Undang-undang

${ }^{6}$ Gunawan Setiardja, Hak-hak Asasi Manusia Berdasarkan Ideologi Pancasila, (Yogyakarta: Kanisius, 1993), hal. 74-76. 


\section{Lindra Darnela}

Dasar Indonesia memang telah mengalami beberapa kali perubahan, sampai akhirnya kembali kepada Undang-undang Dasar 1945. Semenjak Masa Orde Baru hingga saat ini UUD 1945 telah mengalami empat kali amandemen, namun bagian Pembukaan tidak mengalami perubahan karena memuat cita-cita bangsa Indonesia.

1. Pereode kolonial

Pada Pereode ini terjadi "pembaratan" terhadap sistem hukum adat. Penerapan hukum adat sebagaimana dituangkan dalam pasal $75 \mathrm{RR}$, bahwa jika orang Indonesia yang tidak menyatakan dengan sukarela bahwa ia akan dikuasai oleh hukum perdata dan hukum dagang Eropa, maka untuk golongan bangsa Indonesia, hakim harus melakukan dalam larangan hukum perdata adat, kecuali hukum adat tersebut tidak bertentangan dengan dasar-dasar keadilan yang umum yang diakui. ${ }^{7}$

2. Pereode Soekarno (1945-1965)

Pereode ini merupakan awal kemerdekaan bangsa Indonesia yang diproklamirkan pada tanggal 17 Agustus 1945 yang direbut dari penjajahan Belanda. Dalam hal ini, sesuai dengan ajaran Hans Kelsen:

Jika pemerintahan baru sanggup mempertabankan undangundang dasar baru dengan cara yang efektif, maka pemerintahan ini dan undang-undang dasarnya berdasarkan bukum internasional, merupakan pemerintahan yang sab dan undang-undang dasar tersebut berlaku bagi negara tersebut. ${ }^{8}$

Oleh karena itu UUD 1945 dalam pereode 1945-1949 merupakan UUD Negara Republik Indonesia yang merdeka. Berbagai peristiwa diselesaikan dalam masa ini seperti Darul Islam di Jawa Barat dan gerakan disintegrasi di Maluku.

\footnotetext{
${ }^{7}$ Ade Maman Suherman, Pengantar Perbandingan Sistem Hukum, Civil law, Common Lan, Islamic Lav (Jakarta: P.T. Raja Grafindo Persada), 2006, hal. 23-40.

${ }^{8}$ Hans Kelsen, General Theory of Lav and State (Cambridge: Harvard University Press, 1945), hal. 368.

' Ismail Suny, Pergeseran Kekuasan Eksekutif: Suatu Penyelidikan dalam Hukum Ketatanegaraan (Jakarta: Aksara Baru, 1990), hal. 13-14.
} 
Dalam konteks hukum internasional, salah satu syarat konstitutif negara adalah adanya pengakuan dari negara lain. Eksistensi Indonesia dimulai dengan adanya pengakuan dari negaranegara Arab pada tahun 1947, dan pengakuan kedaulatan oleh Belanda pada tangal 27 Desember 1949, juga pengakuan dari negara-negara berdaulat lain di dunia. Pada masa ini, pembangunan nasional berintikan pembangunan politik untuk menuju Kemerdekaan Negara Indonesia yang merdeka, bersatu dan berdaulat, tercapai dalam kurun waktu 1947-1965 di bawah pimpinan It. Soekarno sebagai presiden. ${ }^{10}$

Era Soekarno, politik pembangunan hukum, termasuk menentukan sistem hukum "ala Indonesia" dengan memperhatikan kebutuhan internasionalisme modern, tetap menyadarkan pada sistem konstitusi yang mengalami beberapa kali perubahan. Pemberlakuan hukum barat sepanjang tidak bertentangan dengan hukum nasional masih tetap diberlakukan sehingga pemberlakuan sistem hukum barat merupakan sebuah alternatif yang tidak bisa terelakkan.

Sistem pemeritahan pada masa itu adalah liberal dan terbuka. Secara de jure, HAM memperoleh tempat dan pengakuan di dalam konstitusi, akan tetapi kemajuan-kemajuan di dalam bidang penyelenggaraan keadilan sosial dan kemakmuran masyarakat, tidak banyak diciptakan pada masa itu. Sistem politik yang liberal ini telah dianggap gagal untuk mendukung tegaknya masyarakat yang demokratis dan berkeadilan.

Hukum konstitusi Indonesia yang dituangkan dalam UUD 1945, mengandung muatan HAM yang banyak. Dasar falsafah yang mendasari konsep UUD adalah kekeluargaan dan gotong royong. Pasal-pasal dalam UUD 1945 hampir semua memuat tentang hakhak warga negara seperti hak atas pekerjaan, dan penghidupan yang layak. UUD 1945 juga memuat kewajiban warga negara untuk menjunjung hukum tanpa terkecuali, dan memiliki persamaan

\footnotetext{
${ }^{10}$ Ismail Suny, "Pembangunan Hukum Nasional dalam Pembangunan Jangka Panjang”, dalam Politik Pembangunan Hukum Nasiona, (Yogyakarta: UII Pres, 1992), hal. 51-52.
} 


\section{Lindra Darnela}

kedudukan di dalam hukum. UUD 1945 pra amandemen memang hanya memiliki 5 pasal yang menjamin hak-hak warga negara yaitu, pasal 27, 28, 29, 30 dan 31. Hal ini karena Soekarno secara pribadi tidak menyetujui konsep individualisme apapun, dan menyukai kolektivisme dan solidaritas dengan simbol "gotong royong".

Tahun 1959, rezim demokrasi terpimpin mulai berkuasa. Pada masa ini, kondisi hukum dan HAM di Indonesia semakin suram. Rezim demokrasi terpimpin pada dasarnya merupakan rezim yang menolak bentuk apapun pengawasan rakyat terhadap jalannya pemerintahan. Rezim ini memang telah menghasilkan beberapa produk perundang-undangan untuk memfasilitasi terwujudnya keadilan sosial. Undang-undang land-reform dan undang-undang bagi hasil pertanian merupakan produk legislatif yang dilahirkan masa ini. Undang-undang ini dimaksudkan untuk meratakan sumberdaya di kalangan petani Indonesia, namun ternyata belum berhasil membawa kemakmuran bagi masyarakat petani. ${ }^{11}$

Rezim demokrasi terpimpin telah menghasilkan produk hukum yang akhirnya dipakai untuk menindas hak-hak politik dari warga negara yang kritis. Penetapan Presiden tentang arti kegiatan subversif yang dikeluarkan pada tahun 1963 telah menjadi dasar legitimasi bagi tindakan sewenang-wenang pemerintah untuk membungkam dan menindas HAM warga negara, terutama mereka yang kritis terhadap rezim demokrasi terpimpin.

Primordialisme kedaerahan, friksi-friksi yang tajam di antara kelompok-kelompok politik di Indonesia, berpuncak pada maraknya pemberontakan di berbagai daerah. Hal inilah yang menjadikan bubarnya pemerintahan liberal.

\section{Pereode Soeharto (1966-1998)}

Rezim demokrasi terpimpin akhirnya tergusur oleh rezim pemerintahan Orde Baru pada tahun 1966 yang didominasi oleh

"Abdul Hakim G. Nusantara, Politik Hukum Indonesia Jakarta: Yayasan Bantuan Hukum Indonesia, 1988), hal. 15. 
militer. Masa Orde Baru merupakan masa yang penuh dengan janji dan harapan. Sejak awal, para pemimpin Orde Baru tiada hentinya menyatakan komitmen mereka pada tujuan untuk memulihkan kehidupan negara hukum berdasarkan amanat Pancasila dan UUD 1945. Salah satu upaya tersebut adalah dengan memulihkan fungsifungsi lembaga negara sesuai dengan tuntutan dalam UUD 1945. Pada masa ini pula telah dilakukan usaha untuk memulihkan kedudukan lembaga peradilan yang hampir lumpuh pada era demokrasi terpimpin.

Pada pereode ini, pemerintah mengklaim sebuah karya bangsa dengan diberlakukannya KUHAP produk Indonesia, walaupun sebenarnya merupakan "copy" dari KUHAP Belanda. Kebutuhan akan kepastian hukum sebagai konsekuensi dari investasi asing untuk pembangunan, membuat tidak populernya hukum adat dan hukum Islam. Legal transpant atau pencakokan hukum merupakan salah satu metode untuk mensosialisasikan pola-pola yang diadopsi dari luar, seperti Amerika.

Dalam persoalan hukum, pada masa Orde Baru ini, doktrin kepastian hukum dipulihkan kembali, bersama dengan disusunnya tata hirarki perundang-undangan. Pada tahun 1966, telah ditetapkan dengan Ketetapan Majelis Permusyawaratan Rakyat Sementara No XX tentang Sumber Tertib Hukum Republik Indonesia dan Tata Urutan Perundang-undangan yang terdiri dari: Pancasila, Undangundang Dasar Proklamasi dan Surat Perintah 11 Maret 1966. ${ }^{12}$

Rencana Pembangunan Lima tahun I yang diusulkan pemerintah pada tahun 1969 pun mengakui pentingnya peran hukum untuk melaksanakan pembangunan nasional. Kemudian, disebutkan pula bahwa yang dimaksud dengan rule of law mencakup tiga kebijakan yaitu: Pertama, hak asasi manusia diakui dan dilindungi; kedua, bahwa peradilan harus bebas dan tidak memihak; dan ketiga, bahwa asas legalitas akan dipegang teguh, baik dalam hal pemberlakuan hukum formil maupun hukum materil. Memperkuat ide rule

${ }^{12}$ Ibid, hal. 227. 


\section{Lindra Darnela}

of law yang hendak menjamin kebebasan kehakiman, maka dibuatlah sebuah undang-undang tentang kekuasaan kehakiman yaitu Undangundang Pokok Nomor 14 tahun 1970. ${ }^{13}$ Dengan menghayati prinsipprinsip yang terkandung dalam undang-undang ini, ada semangat dan kesungguhan untuk mewujudkan suatu lembaga peradilan yang benar dan merdeka yang merupakan salah satu tiang yang diperlukan untuk menyangga tegaknya negara hukum yang demokratis dan berkeadilan sosial.

Namun pada awal tahun 70-an, Pemerintah Orde Baru menunjukkan sikap berbeda. Bagi Orde Baru, stabilitas politik dan pertumbuhan ekonomi nasional merupakan prioritas utama sehingga produk hukum yang dapat mewujudkan stabilitas politik dan pertumbuhan ekonomi, penting diciptakan. Sebaliknya, produk hukum yang dianggap dapat menghambat, maka dihapuskan atau dirubah.

Pada masa Orde Baru ini, anti imperialisme dan anti kolonialismi tidak lagi dikumandangakan secara khusus sebagai bagian dari strategi nasional. Gantinya adalah persoalan kemiskinan dan kesulitan hidup dikedepankan sebagai permasalahan yang paling mendesak untuk dipecahkan. Pada tahun 1967, setelah lahirnya Surat Perintah Sebelas Maret (Supersemar), perusahaan-perusahan asing yang diambil alih semasa pemerintahan Presiden Soekarno, telah dikembalikan ke tangan pemiliknya. Undang-undang Penanaman Modal Asing pun segera dibuat dan diundangkan untuk menarik investasi asing. ${ }^{14}$ Karena masa ini pembangunan lebih difokuskan pada persoalan ekonomi, maka tepat jika dikatakan bahwa masa Orde Baru dengan kepemimpinan Soeharto ini disebut sebagai "pembangunan ekonomi". Pada masa ini, tingkat kemiskinan semakin berkurang terutama pada tahun 1976 sampai tahun $1987 . .^{15}$

\footnotetext{
${ }^{13}$ Ibid., hal. 228.

${ }^{14}$ Soetandyo Wignjosoebroto, Dari Hukum Kolonial ke Hukum Nasional Jakarta: P.T. Raja Grafindo Persada, 1995), hal. 225.

${ }^{15} \mathrm{~J}$. Suprapto, "Kemiskinan dan distribusi Pendapatan", Business News, 2 Januari 1990.
} 
Presiden Soeharto pada waktu itu diundang sebagai pembicara dalam Konferensi 40 tahun Peringatan Food and Agricultural Organization (FAO) di Roma sebagai wakil dari negara-negara berkembang. Undangan ini merupakan pengakuan hasil-hasil Indonesia yang monumental dalam bidang pertanian. ${ }^{16}$

Stabilitas politik yang dipersepsi oleh pakar pemimpin Pemerintah Orde Baru adalah kontol yang ketat dari pemerintah terhadap kegiatan politik rakyat sehingga konflik-konflik sosial yang cukup intens dan tinggi pada masa sebelumnya dapat dikendalikan. Dengan hal tersebut, maka dapat menghindari adanya gangguanganguan terhadap jalannya pembangunan ekonomi. Dalam hal ini pertumbuhan ekonomi difahami sebagai suatu usaha untuk meningkatkan pendapatan nasional yang berarti meningkatnya pendapatan penduduk Indonesia.

Sebagai akibat dari pemahaman terhadap stabilitas politik dan pertumbuhan ekonomi yang demikian, maka banyak sekali pembatasan-pembatasan yang sangat ketat terhadap HAM, antara lain: hak untuk mengeluarkan pendapat secara bebas baik secara lisan maupun tulisan, hak berserikat atau hak berkumpul, dan hak mogok.

Lembaga peradilan pun kemudian ditata sehingga relatif berada di bawah pengaruh lembaga eksekutif. Selain itu, pemerintah Orde Baru juga mempertahankan produk hukum dari zaman demokrasi terpimpin yang justru dapat menjadi sumber penyalahgunaan kekuasaan. Penetapan Presiden No 11 tahun 1983 tentang Kegiatan Subversif diadopsi menjadi undang-undang. Undang-undang ini paling sering digunakan untuk membungkam, menangkap dan memenjarakan para warga negara yang senantiasa kritis terhadap sikap dan kebijakan pemerintah. ${ }^{17}$

${ }^{16}$ Anne Booth, Agricultural Development in Indonesia, (Sydney: Allen \& Unwin Australia Pty Ltd., 1988), hal. 1.

${ }^{17}$ Nusantara, Politik Huksum, hal. 18-19. 


\section{Lindra Darnela}

Bisa dikatakan bahwa pranata-pranata hukum pada masa Orde Baru lebih banyak dibangun dengan tujuan:

a) Sebagai sarana legitimasi kekuasaan pemerintah

b) Sebagai sarana untuk memfasilitasi pertumbuhan ekonomi

c) Sebagai sarana untuk memfasilitasi proses rekayasa sosial.

Sebagai akibatnya, hukum belum berfungsi sepenuhnya sebagai sarana untuk melindungi dan mengangkat martabat rakyat, terutama rakyat miskin. Meskipun demikian, Orde Baru memiliki prestasi dengan lahirnya beberapa peraturan yang protektif dan fasilitatif terhadap hak-hak dan kepentingan rakyat. Misalnya: Undang-undang Hukum Acara Pidana yang mengakui hak-hak tersangka dalam proses pidana, dan Undang-Undang Lingkungan Hidup yang mengakui hak rakyat untuk berperan dalam pengelolaan lingkungan hidup.

\section{Pereode pasca Soeharto (1995-Sekarang)}

Pasca Soeharto, nasib hukum adat dan juga termasuk hukum Islam yang sebelum masa kolonial merupakan sistem hukum yang tumbuh dan berkembang dalam masyarakat Indonesia, pada masa ini kedua sistem hukum ini semakin bergeser dan tercerabut dari akar budaya masyarakat karena tidak mampu menahan derasnya keperkasaan sistem hukum Barat. Fenomena ini juga telah dialami oleh masyarakat Eropa ketika mereka masih menggunakan hukum kebiasaan, hukum feodal dan hukum gereja yang akhirnya terdesak oleh hukum code civil yang bersumber dari hukum Romawi.

Sistem hukum nasional Indonesia memang tidak bisa lepas dari sistem hukum Belanda yang telah menjajah selama 350 tahun. KUHP Indonesia, nyaris merupakan copy dari code civil Belanda. Namun, Indonesia memiliki nilai hukum lain selain hukum barat, yaitu hukum adat dan hukum Islam. Dua hukum ini menjadi bagian dari sistem hukum yang membentuk hukum di Indonesia. Masingmasing berintegrasi dan menyesuaikan dengan lokalitas dan modernitas yang berlaku di Indonesia. 
Pada masa ini Indonesia mengalami reformasi kepemimpinan dengan turunnya Rezim Orde Baru yang dipimpin oleh Soeharto. Bisa dikatakan bahwa awal dekade ini, euforia reformasi yang ditandai dengan kebebasan berpendapat dan berekspresi semakin menjamur di berbagai kalangan masyarakat. Namun, dengan lepasnya kontrol dari pemerintah ini, nilai-nilai dalam masyarakat seolah tercerabut seperti menjamurnya tabloid-tabloid yang menampilkan pornografi.

Persoalan lain muncul dengan adanya kebebasan ini, tidak hanya dalam masalah politik, juga krisis moneter yang menjatuhkan perekonomian Indonesia, sehingga menaikkan tingkat kemiskinan. Penataan kembali sistem kenegaraan perlu dilakukan, juga dengan penataan berbagai aspek dalam kehidupan bernegara dan masyarakat. Untuk itu, masa ini lebih tepat jika dikatakan sebagai masa pembangunan hukum. Dengan pembangunan hukum ini, tidak berarti berhentinya pembangunan ekonomi, sosial-budaya, politik dan pertahanan keamanan. Dengan pembangunan hukum, merupakan langkah awal untuk pembangunan sektor lainnya, karena dengan kebebasan yang tidak terarah, hukum saat ini berfungsi sebagai social control.

Di era Reformasi, kejatuhan Orde Baru pada penghujung tahun 1998, memberikan landasan pengalaman bagi sebuah "kesepakatan baru" bahwa proses demokratisasi harus berjalan di bawah payung supremasi hukum. Dengan kata lain, hukum harus memberikan jaminan bagi terselenggaranya sistem yang lebih demokratis dan menjamin terpenuhinya HAM. Aspek perundangundangan di bidang sosial politik, HAM, pemberantasan $\mathrm{KKN}$, kemerdekaan kekuasaan kehakiman, penyesuaian terhadap standarstandar baku internasional, perangkat hukum menghadapai pasar bebas, terus dilakukan untuk sesegera mungkin mengatasi penyalahgunaan kekuasaan, pelanggaran HAM dan pemberantasan KKN agar dapat menumbuhkan kepercayaan di dalam dan di luar negeri sebagai pra-kondisi untuk masuk secara terhormat dalam pergaulan internasional. Instrumentalisasi dan politisasai hukum 


\section{Lindra Darnela}

diusahakan untuk selalu mematuhi asas-asas hukum, dengan keyakinan bahwa suatu sistem politik yang baik akan menghasilkan produk hukum yang baik pula. ${ }^{18}$

Di setiap negara yang mengklaim penganut prinsip demokrasi, partisipasi politik merupakan isu yang sangat penting. Partai politik ${ }^{19}$ merupakan salah satu sarana untuk menyalurkan aspirasi politik massa. Fungsi partai yang utama adalah mengartikulasikan kepentingan sekelompok orang, dan menempatkan wakil-wakilnya dalam jaringan pengambil keputusan sehingga kepentingan tersebut dapat diakui sebagai kepentingan bersama masyarakat yang lebih luas.

\section{Perjalanan Peraturan HAM di Indonesia}

Dalam perspektif Indonesia, proses pencarian makna HAM sebenarnya telah melalui suatu proses sejarah yang panjang. Dalam perspektif historis, dapat ditemukan adanya beberapa perdebatan yang mengarah kepada upaya perumusan konsepsi HAM menurut Indonesia, di antaranya di dalam persidangan Badan Penyelidik Usaha-usaha Persiapan Kemerdekaan (BPUPK) dan Panitia Persiapan Kemerdekaan Indonesia (PPKI) sebelum masa kemerdekaan pada tahun 1945, kemudian pada pertengahan tahun 1950-an, dan ketika Orde Baru mulai tampil ke panggung kekuasaan pada tahun 1965.

Setelah pereode tersebut, kata HAM seolah-olah menghilang dari kamus sehari-hari, dan hanya dipergunakan secara terbatas di kalangan ahli hukum, mahasiswa, dan aktivis HAM. HAM kemudian mengalami masa diam yang panjang di masyarakat Indonesia. Hal ini menjadi fakta yang dapat menjelaskan mengapa ditemui permasalahan untuk memahami pengertian substantif dari HAM.

${ }^{18}$ Muladi, Demokratisasi, Hak Asasi Manusia, dan Reformasi Hukum Indonesia, (Jakarta: The Habibie Center, 2002), hal. 232-233.

${ }^{19}$ Partai politik didefinisikan sebagai "Any political group identified by an official label that presents at elections, and is capable of placing through elections (free or non free), candidates for public offices." Lihat Giovanni Sartori, Parties and Party System: A Framenvork for Analysis (New York: Cambridge University Press, 1976), hal. 63. 
Masalah HAM yang dihadapi oleh Indonesia tidak hanya sekedar soal definisi, namun juga berkaitan dengan pemahaman terhadap ide-ide dasar dari HAM, asal usul mereka dan mekanisme penegakannya. ${ }^{20}$

Sejak awal kemerdekaan Indonesia, berbagai pendapat muncul seputar HAM, apakah perlu menjadi dasar hukum Indonesia atau tidak. Soekarno merupakan salah seorang yang tidak menyetujui HAM dimasukkan dalam UUD, dengan alasan bahwa hak-hak asasi akan menimbulkan adanya berbagai konflik atau pertentangan dalam masyarakat. Alasan lain adalah hak-hak asasi dianggap sebagai gagasan yang bersumber pada individualisme yang melahirkan liberalisme, kapitalisme. Juga menurut Soekarno, HAM tidak ada artinya dibandingkan dengan problem-problem yang menyangkut keadilan. $^{21}$

Di Indonesia, usaha-usaha untuk mewujudkan suatu negara yang demokratis dan melindungi HAM, mengalami pasang surut. Pada masa sesudah kemerdekaan, yaitu pereode 1949-1959 tidak banyak usaha yang dilakukan oleh kelompok-kelompok sosial di Indonesia untuk mewujudkan aspirasi dari para pendiri Republik Indonesia.

Dalam perjalanan sejarah, Konstitusi Republik Indonesia Serikat (RIS) 1949 dan Undang-undang Dasar Sementara (UUDS) 1950, justru memuat pasal-pasal tentang HAM yang lebih banyak dan lebih lengkap dibandingkan dengan UUD 1945. Bahkan bisa dikatakan bahwa kedua UUD tersebut mendasarkan ketentuan HAM-nya pada pernyataan Umum tentang Hak Asasi Manusia (Universal Declaration of Human Rights) yang mulai berlaku pada tanggal 10 Desember $1948 .{ }^{22}$

${ }^{20}$ Todung Mulya Lubis, In Search of Human Rigbts: Logal-Potitical Dilemmas of Indomesia's Nen Onder 1966-1990 (Jakarta: P.T. Gramedia Pustaka Utama in cooperation with SPES Foundation, 1993), hal.13.

${ }^{21}$ Gunawan Setiardja, Hak-bak Asasi Manusia Berdasarkan Ideologi Pancasila (Yogyakarta: Kanisius, 1993), hal. 128-129.

${ }^{n}$ Satya Arinanto, Hak Asasi Manusia dalam Transisi Politik di Indomesia (Jakarta: Pusat Studi Hukum Tata Negara Fakultas Hukum Universitas Indonesia, 2003), hal.10. 
Dalam Konstitusi RIS 1949, pengaturan tentang HAM terdapat dalam bagian V yang berjudul "Hak-hak dan Kebebasankebebasan Dasar Manusia” Pada bagian tersebut, terdapat 27 pasal, dari pasal 7 sampai pasal $33^{23}$. Pasal-pasal tentang HAM yang isinya hampir keseluruhan serupa dengan Konstitusi RIS 1949 juga tercatat dalam UUDS 1950. Di dalam UUDS 1950, pasal-pasal tersebut juga terdapat Bagian V yang berjudul "Hak-hak dan Kebebasankebebasan Dasar Manusia”. Bagian ini terdiri dari 28 pasal dari Pasal 7 sampai dengan Pasal 34. ${ }^{24}$

Kurangnya ketentuan-ketentuan yang berkaitan dengan HAM di dalam UUD 1945 membuat banyak pihak berusaha melengkapinya, di antaranya dengan menyusun suatu Piagam HAM, sebagaimana yang dilakukan oleh Majelis Permusyawaratan Rakyat Sementara (MPRS). Dalam sidang-sidang yang dilakukan di awal Orde Baru, MPRS telah berhasil merancang dokumen yang diberi nama "Piagam Hak-hak Asasi Manusia dan Hak-hak Serta Kewajiban Warga Negara". Akan tetapi kedua piagam tersebut gagal disahkan karena Soeharto yang saat itu sebagai Pejabat Presiden, ingin segera dilantik menjadi Presiden Penuh sebelum ia berangkat ke Tokyo mengikuti Sidang Intergovermental Group on Indonesia (IGGI) yang pertama. Dengan dilantiknya Soeharto sebagai presiden, akhirnya MPRS tidak mengadakan persidangan lagi. Dengan demikian, pembahasan "Piagam Hak-hak Asasi Manusia dan Hakhak Serta Kewajiban Warga Negara” itu pun menjadi tidak jelas nasibnya dan tidak jadi diberlakukan. ${ }^{25}$

Dalam perjalanannya kemudian, Pemerintah Orde Baru seakan-akan bersikap anti terhadap eksistensi suatu Piagam HAM. Setiap pertanyaan yang mengarah kepada perlunya Piagam HAM, cenderung dijawab bahwa Piagam seperti itu tidak dibutuhkan,

\footnotetext{
${ }^{23}$ Suraji, Pularjono, dan Tim Redaksi Tatanusa, Undang-sendang Dasar Negara Republik Indonesia (Jakarta: PT. Tatanusa, 2000), hal. 139-144.

24 Ibid, hal. 88.

${ }^{25}$ Arinanto, Hak Asasi Manusia, hal. 11-13.

${ }^{26}$ Idem, Hukem dan Demokerasi (Jakarta: Ind-Hill-Co, 1991), hal. 30.
} 
karena masalah HAM telah diatur dalam berbagai peraturan perundang-undangan. ${ }^{26}$

Pada tanggal 23 September 1999 diberlakukanlah Undangudang Nomor 39 Tahun 1999 tentang Hak Asasi Manusia. Dalam undang-undang ini, selain diatur mengenai Hak Asasi Manusia dan Kebebasan Dasar Manusia, ditegaskan pula beberapa hal yang berkaitan dengan "Kewajiban Dasar Manusia". Hak-hak asasi manusia dan kebebasan dasar manusia yang ditetapkan dalam UU HAM ini antara lain: hak untuk hidup, hak berkeluarga dan melanjutkan keturunan, hak mengembangkan diri, hak memperoleh keadilan, hak atas kebebasan pribadi, hak atas rasa aman, hak atas kesejahteraan, hak turut serta dalam pemerintahan, hak anak, dan hak perempuan. ${ }^{27}$

Kewajiban dasar manusia yang diatur dalam UU HAM di antaranya:

1 etiap warga negara wajib ikut serta dalam upaya pembelaan negara sesuai dengan ketentuan peraturan perundang-undangan..$^{28}$

2 Setiap orang wajib menghormati hak asasi manusia lain, moral, etika, dan tata tertib kehidupan bermasyarakat, berbangsa, dan bernegara. $^{29}$

3 Setiap hak asasi manusia seseorang menimbulkan kewajian dasar dan tanggung jawab untuk menghormati hak asasi orang lain secara timbal balik serta menjadi tugas pemerintah untuk menghormati, melindungi, menegakkan dan memajukannya. ${ }^{30}$

Babak selanjutnya yang sangat penting bagi penegakan HAM dalam era reformasi adalah ditetapkannya Perubahan Kedua UUD 1945 dalam Sidang Tahunan MPR yang pertama pada tanggal 7-18 Agustus 2000. Sidang tersebut berhasil menetapkan Bab Khusus

${ }^{27}$ Undang-Undang No. 39 Tabun 1999 tentang Hak Asasi Manusia, LN Nomor 165 Tahun 1999, TLN Nomor 3886.

${ }^{28}$ Ibid., Pasal 68

29 Ibid., Pasal 69 ayat (1).

${ }^{30}$ Ibid., Pasal 59. 


\section{Lindra Darnela}

yang mengatur HAM dalam Bab XA. Isi Bab tersebut memperluas Pasal 28 UUD 1945 yang semula hanya terdiri dari 1 pasal dan 1 ayat, menjadi beberapa pasal dan beberapa ayat. Pasal-pasal dan ayat-ayat tersebut tercantum dalam pasal 28A sampai dengan Pasal 28J. Secara redaksional, pasal-pasal tersebut memiliki kesamaan dengan beberapa pasal dari Ketetapan MPR Nomor XVII/MPR/ 1998 dan UU Nomor 39 Tahun 1999.

Dengan banyaknya kasus-kasus pelanggaran HAM yang tidak dapat diselesaikan, maka pada tahun 2000, MPR mengesahkan Undang-undang Nomor 26 tahun 2000 tentang Pengadilan Hak Asasi Manusia. Menjelang digelarnya pelaksanaan Pengadilan HAM Ad Hoc untuk kasus pelanggaran berat HAM yang terjadi di Timor Timur, pemerintah menerbitkan Peraturan Pemerintah Nomor 2 Tahun 1999 tentang Tata Cara Perlindungan Terhadap Korban dan Saksi dalam Pelanggaran Hak Asasi Manusia yang Berat, dan Peraturan Nomor 3 Tahun 1999 tentang Kompensasi, Restitusi, dan Rehabilitasi terhadap Korban Pelanggaran Hak Asasi Manusia yang Berat. Penerbitan dua PP ini merupakan pelaksanaan dari Pasal 34 ayat (3) dan 35 ayat (3) UU Nomor 26 Tahun 2000 tentang Pengadilan HAM.

\section{E. Membangun Hukum yang Responsif}

Jika melihat alur ke belakang, terlihat bahwa zaman Soekarno menampakkan sosok wajah hukum yang refresif. Alasan utamanya karena kepentingan revolusi yang saat itu menjadi "tesis perjuangan politik Soekarno". Contohnya dalam UU Nomor 19 tahun 1964, diatur bahwa demi kepentingan revolusi Presiden dapat mencampuri urusan pengadilan; Ketua Mahkamah Agung merupakan Anggota Kabinet. ${ }^{31}$ Pada masa Orde Lama, sejak era 1950-1965, pemerintah disibukkan dengan usaha untuk membangun kesadaran akan hidup berbangsa. Aspek bernegara lain yang tidak kalah pentingnya, yaitu ekonomi, hampir tidak mendapat perhatian untuk ditangani secara serius.

\footnotetext{
${ }^{31}$ Muladi, Demokratisasi, hal. 231.
} 
Pada masa Orde Baru, Kelalaian Orde Lama dikoreksi oleh Pemerintah Orde Baru melalui rangkaian pembangunan ekonomi sejak 1969. Pemerintah Orde Baru melaksanakan strategi pembangunan ekonomi yang bersifat teknokratik. ${ }^{32}$ Selain itu, pemerintah juga meletakkan stabilitas politik sebagai prasyarat bagi pembangunan ekonomi. Pemerintah membutuhkan modal asing untuk memulai pembangunan ekonomi, sehingga pemerintah harus berhutang kepada Lembaga-lembaga Keuangan Internasional (LKI) seperti International Monetary Fund (IMF) dan Word Bank. Para penanam modal asing, mansyaratkan adanya stabilitas politik untuk mengamankan modal mereka. Dengan alasaan ini, pemerintah dengan sengaja telah membangun brikade-brikade demi terciptanya stabilitas politik.

Penetrasi negara ke dalam masyarakat desa berjalan sangat efektif pada masa Orde Baru. Selain dengan masuknya administrasi territorial militer yang sejajar dengan jaringan sipil, juga dengan adanya perwakilan kepentingan yang menghubungkan Negara dan masyarakat melalui jaringan organisasi-organisasi fungsional nonideologis yang dalam literatur disebut sebagai koorporatisme Negara. Penerapan mekanisme ini telah menghilangkan kemajemukan dalam kehidupan sosial politik pedesaan dan memunculkan pengorganisasian kepentingan masyarakat dalam wadah-wadah yang serba tunggal. Organisasi-organisasi tersebut adalah KORPRI, HKTI, HNSI, PKK, Karang Taruna, KNPI, KUD. ${ }^{33}$ Ormas-ormas tersebut menjadi satu-satunya penyambung antara negara dan masyarakat. Karena mekanisme inilah yang diyakini bisa "meminimalkan konflik sosial dan memaksimalkan produktivitas ekonomi

Seperangkat aparatur keamanan dibentuk seperti Kopkamtib, Bakin, Opsus dan Ditjensospol. Aparatur ini dilengkapi dengan

${ }^{32}$ Model ini bercirikan rendahnya partisipasi politik masyarakat, tingginya penanaman modal (terutama modal asing), meningkatnya pertumbuhan ekonomi, tetapi secara bersamaan meningkatkan ketimpangan pendapatan (income inequahity). Lihat: Samuel Huntington and Joan Nelson, No Easy Choice (Cambridge: Harvard University Press, 1976), hal. 22.

${ }^{33}$ Mohtar Mas'oed, Politik, Birokrasi, dan Pembangunan, cet. 2 (Yogyakarta: Pustaka Pelajar, 1997), hal. 130-132.

Al-Manāhij, Vol. 3 No. 1 Januari - Juni 2009 


\section{Lindra Darnela}

empat larangan yang disebut sebagai The Four Dont's meliputi: Larangan melakukan intimidasi terhadap lawan politik; Larangan menghina harga diri pemerintah beserta aparatnya; Larangan mengganggu kesatuan nasional; dan larangan mengkritik kebijakan pemerintah. ${ }^{34}$ Ketiga larangan pertama berusaha menjaga kesatuan dan sekaligus meningkatkan kesadaran akan hidup berbangsa. Namun larangan keempat, ternyata telah meminimalkan (kalau tidak menghapuskan) kesempatan bagai masyarakat untuk berpartisipasi dalam politik. Dalam hal ini masyarakat tidak bisa aktif mengemukakan pendapatnya karena ada larangan untuk mengevaluasi kebijakan yang dilakukan oleh pemerintah.

Strategi pembangunan ekonomi yang teknoratis dipadukan dengan stabilitas politik sebagai ciri demokrasi, menghasilkan dua arus yang berlawanan. Secara ekonomis, dengan mengalirnya modal asing untuk membantu Indonesia, telah membawa Indonesia ke arah ekonomi global yang diharapkan mampu bersaing dengan industri negara-negara lain. Secara politis, dengan mengurangi hak-hak warga negara seperti kesempatan mengoreksi kebijakan pemerintah, telah menyeret Indonesia ke dalam bentuk autboritarian policy.

Masa pasca Orde Baru terdapat indikator-indikator yang dapat digeneralisasi untuk menggambarkan telah terjadinya kerusakan sistemik di dalam kehidupan hukum sebagai warisan Orde Baru masih nampak jelas kelihatan. Indikator-indikator tersebut antara lain belum terciptanya kekuasaan kehakiman yang merdeka. Para ahli hukum baik secara teoritis maupun praktisi kurang memberikan reaksi secara proporsional dan profesional. Ada semacam "keacuhan kolektif", yang pada gilirannya memicu krisis terhadap asas-asas hukum.

Adanya "mafia peradilan" masih menjadi anggapan di tengah masyarakat tanpa adanya langkah-langkah signifikan untuk mengatasinya. Kesadaran hukum baik di lingkungan para penegak

${ }^{34}$ David Jenkins, Subarto and His Generals: Indonesian Military Politics 1975-1983, (New York: Cornell Modern Indonesian Project, 1984), hal. 42. 
hukum maupun masyarakat masih terasa sangat lemah. Kegagalan menciptakan keadilan oleh penegak hukum masih sering terjadi, dibarengi dengan masih banyaknya terjadi tindakan anomis serta perbuatan main hakim sendiri (eigen richting) di lingkungan masyarakat.

Selain hal tersebut di atas, harmonisasi hukum terhadap standar-standar baku universal di bidang HAM, baik menyangkut hak-hak sipil politik, sosial, ekonomi, budaya dan hak atas pembangunan, masih jauh dari memadai. Ratifikasi terhadap konvensi internasional lebih mengesankan sebagai langkah windowdressing, ketimbang sebagai langkah-langkah sistematis yang serius. Beberapa konvensi internasional yang penting menyangkut hak-hak kelompok marginal seperti trafficking dan perlindungan terhadap buruh migran, belum juga diratifikasi oleh Pemerintah Indonesia.

Selain berdimensi nasional, instrumentalisasi atau politisasi hukum saat ini juga berdimensi internasional dengan adanya proses globalisasi yang sarat akan kepentingan politik, ekonomi, dan sebagainya. Proses globalisasi yang menggeser orientasi konsep kepentingan dan kesejahteraan regional dan global, jelas didominasi oleh negara-negara maju secara ekonomi. Standar-standar baku yang lebih menguntungkan kepentingan mereka secara sistematis diterapkan di seluruh dunia. Standar baku tersebut tidak hanya berkaitan dengan kehidupan ekonomi, tetapi juga di bidang politik sebagi kerangka dasarnya. Sebagai contoh, pasar bebas hanya mungkin terjadi di dalam kehidupan demokrasi yang menjunjung tinggi dan perlindungan HAM, pemerintahan yang transparan dan akuntabel serta kehidupan masyarakat madani yang sehat.

Dalam menentukan peranan sosial hukum, masalah yang sama akan dialami pula bagi para pengambil kebijakan. Pertanyaan selanjutnya adalah, peranan sosial hukum bagaimana yang kita butuhkan dalam kondisi masyarakat Indonesia saat ini? Apakah peranannya sebagai alat rekayasa sosial (social engineering) guna memacu mobilitas pembangunan, atau sebagai sarana pengarah dan 


\section{Lindra Darnela}

pengendali perubahan sosial (social control), atau peranannya sebagai instrumen untuk mewujudkan keadilan?

Meskipun persoalan di atas kelihatan dikotomis, tetapi sebenarnya pilihan-pilihan itu dapat diintegrasikan, artinya bagaimana menyelaraskan dan menyeimbangkan nilai-nilai, bentuk dan isi, serta peranan sosial hukum itu dalam pembuatan kebijakan. Warna dan corak hukum lebih banyak ditentukan oleh cara pandang dan kemauan politik lembaga legislatif dan eksekutif sebagai institusi pembuat undang-undang. Namun demikian, kelompok-kelompok sosial masyarakat yang ikut berpartisipasi, akan mempengaruhinya pula. Kearifan dalam menyelaraskan dan menyeimbangkan pilihanpilihan nilai tersebut sangat diperlukan, guna mengeliminir akibatakibat negatif yang mungkin timbul.

Dalam hal ini ada suatu tantangan yaitu bagaimana merumuskan dan membangun suatu sistem nilai nasional yang sesuai dengan kebutuhan zaman, namun tetap berpijak pada nilai-nilai kultural bangsa. Pembangunan hukum nasional harus mempertimbangkan bukan hanya aspek filosofis dan ideologis, tetapi juga aspirasi yang tumbuh dalam masyarakat. $\mathrm{Hal}$ ini berarti memenuhi hukum memenuhi tuntutan ideal dan menjawab kenyataan sosial sekaligus.

Dalam perspektif sosial, peranan yang diharapkan dari hukum dalam kehidupan masyarakat adalah menunjang dan mendukung pembangunan di segala aspek kehidupan masyarakat. Hukum harus didayagunakan untuk memacu perputaran roda pembangunan. Hukum juga harus difungsikan untuk mengarahkan dan mengendalikan laju perkembangan masyarakat. Namun yang lebih penting dari kedua hal tersebut di atas adalah: hukum harus memberikan pedoman dan ukuran tentang prinsip-prinsip keadilan dan HAM dalam kehidupan masyarakat bernegara, karena ini merupakan tugas pokok hukum.

Hukum dalam hal ini diharapkan bukan hanya sebagai metode penyelesaian konflik, tetapi juga sebagai sarana perubahan sosial 
dan penjamin hak-hak asasi manusia. Kenyataannya bahwa hukum selalu mencerminkan perimbangan kekuatan dalam masyarakat pada saat hukum itu dibuat. Kekuasaan sangat menentukan agenda setting bagi proses pembuatan keputusan. Oleh karena itu, yang berkuasa lebih menentukan isi agenda kerja proses pembuatan hukum tersebut, sehingga nilai-nilai yang masuk dan kepentingan-kepentingan yang mendasari usulan undang-undang yang diajukan dalam proses itu adalah yang bisa diterima oleh yang paling berkuasa.

Di Indonesia, yang terjadi adalah perubahan dari ekstrem satu ke ekstrem lainnya yang mengakibatkan pergeseran yang radikal dari kekuasaan yang terpusat menjadi sangat tersebar. Pada saat yang sama, pergeseran tersebut tidak berhasil mengatasi problem yang dihadapi setelah krisis, berbeda dengan kondisi Thailand dan Korea Selatan yang mengalami pemulihan ekonomi dengan cepat selepas krisis. Saat ini, Indonesia memiliki demokrasi sebagai salah satu kekayaan, tetapi konsekuensi dengan adanya demokrasi yang yang tengah berjalan adalah pemerintahan yang tidak efektif. Agenda selanjutnya adalah bagaimana meminimalisir akibat negatif dari demokrasi dan menyamakan irama antara demokratisasi dan pemerataan hasil pembangunan ekonomi.

Beberapa prioritas kebijakan yang kini menjadi agenda global adalah penyebarluasan demokrasi, perlindungan HAM, pencegahan dan penyelesaian konflik komunal, ketidakamanan ekonomi akibat pasar bebas, dan menurunnya daya dukung lingkungan hidup. Semua agenda itu merupakan produk globalisasi yang kini melanda dunia. Oleh karena itu diplomasi dan politik luar negeri RI juga dituntut kemahirannya dalam memainkan peran dalam menghadapi isu-isu global itu.

Dalam persoalan politik luar negeri, harus memunculkan sosok perimbangan antara komitmen pemenuhan kebutuhan penegakan HAM, misalnya, dan kewajiban nasional dalam mengatur hubungan luar negeri RI yang lebih sehat dan dinamis. Meminjam konsep yang diberikan Rein Mullerson, Indonesia perlu mengedepankan buman 


\section{Lindra Darnela}

rights diplomacy sebagai bagian penting dari total diplomacy yang dicanangkan Menlu Hasan Wirajuda dan istrumen politik luar negeri "Bebas Aktif" yang dianut RI.

Penggunaan buman rights diplomacy menjadi tak terhindarkan di tengah perubahan konstelasi politik global. Sementara itu, pelaksanaan diplomasi HAM hanya dapat dilaksanakan secara efektif bila suatu negara memiliki catatan penegakan HAM yang relatif baik dan tinggi. Untuk meningkatkan pencapaian HAM, negara harus melakukan banyak perbaikan, seperti di bidang pembangunan ekonomi, pendidikan, kesehatan, dan bidang-bidang kehidupan sosial lainnya.

Sementara itu, rendahnya pembangunan di berbagai bidang, terutama disebabkan tingkat korupsi yang merajalela yang terjadi dalam suatu negara. Oleh karena itu, catatan penegakan HAM yang amat rendah akan menjadi penghalang utama penggunaan diplomasi HAM baik di forum multilateral dan bilateral.

Dengan demikian, elemen diplomasi, pembangunan ekonomi, demokratisasi, dan penegakan hukum dan HAM yang responsif, akan saling mempengaruhi pembuatan dan pelaksanaan politik luar negeri yang menyeluruh guna mencapai tujuan pembangunan nasional.

\section{F. Kesimpulan}

Pembangunan hukum di Indonesia mengalami pasang surut sejak pereode pemerintahan Belanda sampai sekarang. Pada pereode pemerintah kolonial Belanda terjadi "pembaratan" terhadap sistem hukum adat sehingga nilai-nilai budaya yang ada dalam masyarakat mulai dibekukan meskipun akhirnya diakui adanya tiga sistem hukum yang berlaku yaitu: hukum adat, hukum Islam, dan hukum Belanda.

Pereode Soekarno, yang merupakan awal kemerdekaan Indonesia, menghasilkan produk hukum yang berupa legal transpant atau pencakokan hukum dari hukum asing. Sedangkan pada Pereode Orde Baru di bawah pimpinan Soeharto, doktrin kepastian hukum dipulihkan kembali, bersama dengan disusunnya tata urutan 
perundang-undangan. Pembangunan, termasuk pembangunan hukum, lebih difokuskan pada persoalan ekonomi sehingga masa ini disebut sebagai "pembangunan ekonomi".

Pasca Soeharto hukum adat dan juga hukum Islam yang sebelum masa kolonial merupakan sistem hukum yang tumbuh dan berkembang dalam masyarakat Indonesia semakin mengalami pergeseran dan tercerabut dari akar budaya masyarakat karena tidak mampu menahan derasnya keperkasaan sistem hukum Barat. Ratifikasi terhadap konvensi internasional lebih mengesankan sebagai langkah windowdressing, ketimbang sebagai langkah-langkah sistematis yang serius.

Usaha-usaha untuk mewujudkan suatu negara yang demokratis dan melindungi HAM pun mengalami pasang surut. Pada masa sesudah kemerdekaan, yaitu pereode 1949-1959 tidak banyak usaha untuk mewujudkan aspirasi dari para pendiri Republik Indonesia, termasuk dengan dibuatnya UUD 1945 yang dianggap kurang memuat perlindungan HAM. Konstitusi Republik Indonesia Serikat (RIS) 1949 dan Undang-Undang Dasar Sementara (UUDS) 1950 justru memuat pasal-pasal tentang HAM yang lebih banyak dan lebih lengkap dibandingkan dengan UUD 1945.

Kurangnya ketentuan-ketentuan yang berkaitan dengan HAM di dalam UUD 1945 membuat banyak pihak berusaha melengkapinya, di antaranya dengan menyusun suatu Piagam HAM, sebagaimana yang dilakukan oleh Majelis Permusyawaratan Rakyat Sementara (MPRS). Dalam sidang-sidang yang dilakukan di awal Orde Baru, MPRS telah berhasil merancang suatu dokumen yang diberi nama "Piagam Hak-Hak Asasi Manusia dan Hak-hak Serta Kewajiban Warga Negara”. Akan tetapi kedua piagam tersebut gagal disahkan karena Soeharto yang saat itu sebagai Pejabat Presiden bersikap anti terhadap eksistensi Piagam HAM. Setiap pertanyaan yang mengarah kepada perlunya Piagam HAM selalu dijawab bahwa Piagam seperti itu tidak dibutuhkan, karena masalah HAM telah diatur dalam berbagai peraturan perundang-undangan. 


\section{Lindra Darnela}

Pada era reformasi ditetapkan Perubahan Kedua UUD 1945 dalam Sidang Tahunan MPR yang pertama pada tanggal 7-18 Agustus 2000. Sidang tersebut berhasil menetapkan Bab Khusus yang mengatur HAM dalam Bab XA. Isi Bab tersebut memperluas Pasal 28 UUD 1945 yang semula hanya terdiri dari 1 pasal dan 1 ayat, menjadi beberapa pasal dan beberapa ayat. Pasal-pasal dan ayat-ayat tersebut tercantum dalam pasal 28A sampai dengan Pasal 28J. Secara redaksional, pasal-pasal tersebut memiliki kesamaan dengan beberapa pasal dari Ketetapan MPR Nomor XVII/MPR/ 1998 dan UU Nomor 39 Tahun 1999. Sampai saat ini, amandemen keempat dilakukan, tetapi ketetapan tentang HAM tidak merubah ketetapan dalam amandemen kedua. 


\section{DAFTAR PUSTAKA}

Arinanto, Satya. Hukum dan Demokrasi. Jakarta: Ind-Hill-Co.,1991. . Hak Asasi Manusia dalam Transisi Politik di Indonesia. Jakarta: Pusat Studi Hukum Tata Negara Fakultas Hukum Universitas Indonesia, 2003.

Booth, Anne. Agricultural Development in Indonesia. Sydney: Allen \& Unwin Australia Pty Ltd., 1988.

Cranston, Maurice. What are Human Rights? New York: Taplinger, 1973.

Donnely, Jack. Universal Human Rights in Theory and Practice. Ithaca and London: Cornell University Press, 2003.

Fakih, Mansour. Runtubnya Teori Pembangunan dan Globalisasi. Yogyakarta: Pustaka pelajar dan Insist Press, 2008.

Huntington, Samuel and Joan Nelson. No easy Choice. Cambridge: Harvard University Press, 1976.

Jenkins, David. Subarto and His Generals: Indonesian Military Politics 1975-1983. New York: Cornell Modern Indonesian Project, 1984.

Kelsen, Hans. General Theory of Law and State. Cambridge: Harvard University Press, 1945.

Lubis, Todung Mulya. In Search of Human Rights: Legal-Political Dilemmas of Indonesia's New Order, 1966-1990. Jakarta: P.T. Gramedia Pustaka Utama in cooperation with SPES Foundation, 1993.

Mas'oed, Mohtar. Politik, Birokrasi dan Pembangunan, Cetakan Kedua, Yogyakarta: Pustaka Pelajar, 1997.

Muladi. Demokratisasi, Hak Asasi Manusia, dan Reformasi Hukum Indonesia, Jakarta: The Habibie Center, 2002. 
Lindra Darnela

Muqoddas, M. Busyro, dkk. Politik Pembangunan Hukum Nasional. Yogyakarta: UII Press, 1992.

Nusantara, Abdul Hakim G. Politik Hukum Indonesia. Jakarta: Yayasan Bantuan Hukum Indonesia, 1988.

Pularjono, Suraji, dan Tim Redaksi Tatanusa. Undang-undang Dasar Negara Republik Indonesia. Jakarta: PT. Tatanusa, 2000.

Sartori, Giovanni. Parties and party System: A Framework for Analysis.

New York: Cambridge University Press, 1976.

Setiardja, Gunawan. Hak-bak Asasi Manusia Berdasarkan Ideologi Pancasila. Yogyakarta: Kanisius, 1993.

Suherman, Ade Maman. Pengantar Perbandingan Sistem Hukum, Civil Law, Common Law, Islamic Law. Jakarta: P.T. Raja Grafindo Persada, 2006.

Suny, Ismail. Pergeseran Keleuasan Elesekutif: Suatu Penyelidikan dalam Hukum Ketatanegaraan. Jakarta: Aksara Baru, 1990.

Wignjosoebroto, Soetandyo. Dari Hukum Kolonial ke Hukum Nasional. Jakarta: P.T. Raja Grafindo Persada, 1995.

Undang-Undang No. 39 Tabun 1999 tentang Hak Asasi Manusia, LN Nomor 165 Tahun 1999, TLN Nomor 3886. 